\title{
Otoriteye Muhalefet: Şehristânî'nin İbn Sînâ'ya Muhalefeti ve Gazzâlîci Muhalefet Tavrını Dönüştürmesi ${ }^{1}$
}

\section{Ömer Ali YILDIRIM*}

Opposition to the Authority: al-Shahrastânî's Oppositon to Ibn Sînâ and the Transformation of al-Ghazzâlî’s Opposition

\section{Attitude}

Citation/C): Yıldırım, Ömer Ali, (2018). Opposition to the Authority: alShahrastânî's Oppositon to Ibn Sînâ and the Transformation of alGhazzâlî's Opposition Attitude, Milel ve Nihal, 15 (2), 170-189.

Abstract: In spite of opposition term is today generally used in a political sense the term also can be used in a wider meaning that all kind of objection and criticism against the person who has power in any field. Sometimes it can be done to stimulate, shake, take over the authority or eliminate it. Ibn Sînâ who is one of the greatest authorities of Islamic Philosophy also faced different oppositions. I have dealt with al-Shahrastânî who wrote a separate critic book to Ibn Sînâ and characteristics of his critics. Based on this book called as Kitâb al-Musâra'a al-Felâsife, I tried to evaluate the nature, real reason and purpose of his opposition to Ibn Sînâ. In accordance with this purpose I have tried to examine this book by comparing with alGhazzâlî's Tahâfut al-Falâsife. By doing so, I aimed to get a general view of the course of this opposite line for Ibn Sînâ and his philosophy after alGhazzâlî. I tried to detect whether this oppositional attitude of al-Ghazzâlî is sustained in a later oppositional book or is tried to be transformed and even so, what is the direction of this transformation.

Keywords: opposition, criticism, al-Shahrastânî, Ibn Sînâ, al-Ghazzâlî, transformation.

1 Bu makale özgün bir çalışma olmakla birlikte bazı noktalarda yazarın Şehristânî'nin İbn Sînâ Eleştirisi adlı kitabındaki fikirlerden esinlenmiş, bu noktalarda da önceki fikir ve çıkarımlar daha da geliştirme yoluna gidilmiştir.

* Dr. Öğr. Üyesi, Selçuk Üniversitesi, İslâmi İlimler Fakültesi, İslam Felsefesi Anabilim Dalı [yildirimomerali@gmail.com]. 
Şehristânî'nin İbn Sînâ'ya Muhalefeti ve Gazzâlîci Muhalefet Taørını Dönüştürmesi

Atıf/C: Yıldırım, Ömer Ali, (2018). Otoriteye Muhalefet: Şehristânînin İbn Sînâ'ya Muhalefeti ve Gazzâlîci Muhalefet Tavrını Dönüştürmesi, Milel ve Nihal, 15 (2), 170-189.

Öz: Muhâlefet terimi günümüzde çoğunlukla siyasi bir anlamda kullanılmakla birlikte bu terim daha geniş bir anlamda belirli bir alandaki güç sahibine karşı yapılan her türlü itiraz anlamında kullanılabilir. Bazen otoriteyi uyarmak, sarsmak, ele geçirmek ya da ortadan kaldırmak için yapılabildiği gibi bazen de onu sağlamlaştırmaya yönelik yapılabilir. İslam felsefesinin önde gelen otoritelerinden biri olan İbn Sînâ da farklı muhalefetlerle karşılaşmıştır. Bu makalede İbn Sînâ'ya yönelik müstakil bir eleştiri kitabı yazan Şehristânî’yi ve onun eleştirilerinin özelliklerini ele almaya çalıştım. Musâra'atü'l-felâsife adlı bu eserinden hareketle onun İbn Sînâ muhalifliğinin mahiyetini, bu muhalefetin gerçek nedenini ve amacını değerlendirmeye çalıştım. Bu amaç doğrultusunda bu eseri Gazzâlî'nin Tehâfütü'/felâsife ile karşılaştırarak ele almaya gayret ettim. Bu sayede İbn Sînâ ve felsefesine yönelik muhalif tavrın Gazzâlî'den sonraki yönüne dair bir bakış yakalamak istedim. Gazzâlî’nin bu muhalif tavrının kendinden sonra kaleme alınmış bir eserde devam mı ettirildiği yoksa dönüştürülmeye mi çaIışıldığını ve bu dönüşümün yönünün ne olduğunu tespit etmeye gayret ettim.

Anahtar Kelimeler: muhalefet, eleştiri, Şehristânî, İbn Sînâ, Gazzâlî, dönüşüm.

\section{Giriș: Muhalefet ve Eleştiri Kavramları}

"Muhalefet" Arapça kökenli bir kelime olup modern dilde daha çok siyasi bir içerikle, iktidar karşıtlığı ve iktidar partisi haricindeki partilere gönderme yapan bir anlamda kullanılmaktadır. Türkçe'deki bu anlamı Arapça'da karşılayan kelime ise "muhalefet" değil "mu'âraza" kelimesidir. Dolayısıyla muhalefet kelimesinin Türkçe'de anlam bakımından farklılaştığını söyleyebiliriz. Kelimenin Arapça' daki kökenine baktığımızda ise daha geniş bir anlamda kullanıldığı görülür. Nitekim siyasi otorite ile ilgili kullanımının yanı sıra hadis ilminde "muhâlefetü'r-râvî", "muhâlefetü's-sika" şeklinde "ayrılmak", "aykırı davranmak" gibi anlamlarda kullanılırken kelâm ilminde "muhâlefetün li'l-havâdis" şeklinde Allah'ın yarattıklarına benzememesini ifade etmek amacıyla bir şeyin diğer bir şeyden farklı olması anlamında kullanılmaktadır. Klasik sözlüklerde bu kelime "halinde ve sözünde her bir kişinin başkasının yolundan farklı olarak kendi yolunu benimsemesi" olarak açıklanmış ve "hilâf" $1 n$, "zıt" tan daha geniş bir anlama geldiği, çünkü bir birine zıt olan her iki şey birbirine muhalif iken birbirine muhalefet eden 
her iki şeyin zıt olmadığı vurgulanmıştır. Yine, ihtilafın insanlar arasında sözlü bir şekilde olduğunda bir çekişme ve mücadeleyi ortaya çıkardığı da ifade edilmiştir. ${ }^{2}$ Muhalefet kelimesinin sözlük anlamına dair yapılan bu açıklamadan ayrıca "hilâf" ve "ihtilâf" kelimelerinin de muhalefetle yakın anlamda olduğu anlaşılmaktadır. Siyaset biliminde ise bu terim karşı olma, direnme, başka görüş ve politikalara kendi görüş ve politikalarıyla karşı olma gibi anlamlarda kullanılmaktadır. ${ }^{3}$

İslam felsefesi tarihinde belirli bir felsefi konuya ya da filozoflara yönelik karşı duruş ise "tehâfüt", "musâra'a", "ibtâl" ve "red" gibi terimlerle ifade edilmiştir. Bu terimler ayrı ayrı incelendiğinde manayı ifade etme gücü bakımından farklılaşmalarına ve de farklı boyutlara gönderme yapmalarına rağmen hemen hepsi de ele alınan konuda ya da hedefe alınan filozofa yönelik bir karşıt tavrı benimseme noktasında birbirine yaklaşmaktadır. Nitekim "tehâfüt" terimi ele alınan konuda filozof ya da filozofların görüşleri arasındaki çelişki üzerinden hareketle bir karşı duruşu ifade ederken "musara'a" ise açık bir biçimde hedefteki filozofla karşılıklı mücadeleyi (güreşmeyi) ifade etmektedir. "İbtâl" terimi Türkçede de kullanıldığı anlama yakın bir biçimde belli bir felsefi teoriyi ya da açıklamayı ortadan kaldırma, geçersiz kılma ve iptal etme anlamına gelirken "red" terimi ise açık bir karşı duruşu ifade etmektedir. Bizim çalışmamız açısından özellikle musâra'a ve tehafüt terimleri öne çıkmaktadır. Musâra'a sözlükte güreş anlamına gelmektedir. Ancak fikri bir karşı duruşu ifade etmek amacıyla kullanıldığında doğrudan karşılıklı bir mücadeleye gönderme yapmaktadır. Burada ifade edilen iki rakibin ya da iki görüşün karşılıklı mücadelesidir. Tehâfüt terimi ise karşılıklı bir mücadeleden çok filozofun felsefesindeki ya da bir görüşündeki içsel tutarlılığı hedef almaktadır. Biz burada her iki terimin de farklı anlamlara gönderme yapmasına rağmen bir karşı duruşu ya da karşı oluşu ifade etmesinden hareketle bunlarla "muhalefet" terimi arasında ortak bir yönün de bulunduğunu dikkate alacağız. Buradan hareketle de felsefi bir eleştirel tavrı yansıtan bu terimleri felsefi bir muhalefet olarak kabul edeceğiz.

2 Ragip el-İsfehânî, el-Müfredât, tahk.: Muhammed Seyid Kîlânî, (Lübnan: Dâru'lMa'rife, th.yok) s. 156.

3 N. S. Aşukin, N. P. Butırskiy vd., Politika Sözlüğü, çev.: Mazlum Beyhan, (İstanbul: Sosyal yay. 1979), s. 361. 
Şehristânî'nin İbn Sînâ'ya Muhalefeti ve Gazzâlîci Muhalefet Taørını Dönüştürmesi

Yukarıdaki kavramlardan tehâfüt ve musâra'a daha çok sırasıyla, Gazzâlî ve Şehristânî'nin kendi eleştirel tavırlarını ifade etmek için tercih ettikleri kavramlardır. Ret kavramı İbn Teymiyye'nin kullandığı bir kavram iken ibtâl kavramı İbn Haldun tarafından kullanılmıştır. Bu kavramların hepsi de eleştirel bir duruşu ifade etmektedir. Bu çalışmada Şehristânî'nin İbn Sînâ felsefesine karşı sergilediği tavır üzerine odaklanacak ve bu tavrı inceleme ve değerlendirme noktasında öncelikli olarak Gazzâlî’nin tavrına kısmen de Ebü'l-Berekât el-Bağdâdî'nin tavrına göndermeler yapacağım.

\section{Muhalif Bir Eser Olarak Musâra'atü'l-felâsife}

Eş'arî bir kelamcı olan Şehristânı̂'nin ${ }^{4}$ en önemli eseri aynı zamanda
ona haklı bir şöhret kazandıran $e l-M i l e l$ ve'n-Nihâl adlı dinler, mez-
hepler ve farklı felsefi okullara dair yazdığı kitabıdır. Bu eserin

4 İslam düşüncesi tarihinde kendisine çok fazla destek ve veri bulamamakla birlikte yirminci yüzyılın ikinci yarısında Şehristânî'nin bazı eserlerini yayınlayan araştırmacılar tarafından onun İsmâilî olduğu gündeme getirilmiştir. M. R. Celâl Nâ‘̂̂nî ve M. T. Dâniş Pejûh gibi araştırmacıların gündeme getirdiği bu iddianın temelde aynı zamanda Şehristânî'nin de derslerine katılan İbnü's-Sem'ânî'den (ö: 1166) Subkî'nin Tabakât'ın da yaptığı bir aktarımdan yola çıktığı ve Şehristânî'nin eserlerinden bu ithamı destekleyecek veriler bulmaya yöneldiği görülmektedir. Ne yukarıda isimlerine işaret edilen araştırmacıların Wilferd Madelung tarafindan tatmin edici bulunmayarak kabul edilmeyen iddiaları ne de bizzat Madelung' un iddia ettiği Şehristânî'nin akide ve dini inancında bazı Şii ve İsmâilî görüşleri benimseyen sosyal ve kültürel olarak Sünni olduğu iddiası kabul edilebilir görünmektedir. Nitekim bizzat Madelung'un kendisinin de yukarıdaki araştırmacılara karşı öne çıkardığı bu görüşlerinin çağdaş Sünni eleştirmenler tarafından desteklenmemesine ek olarak klasik dönemde de -yukarıdaki İbnü's-Sem'ânî üzerinden gündeme getirilen iddianın varlığıyla birlikte- Şehristânî Sünni ve Eş'arî bir kelamcı olarak kabul görmüştür. İbnü's- Sem'ânî üzerinden gündeme getirilen mesele ise rahatllkla o dönemin entelektüel ortamlarında rakiplere yönelik kullanılan bir itham olarak görülebilir. Subkî eserinde hocamız dediği Zehebî'nin Tarîh'inde İbnü's- Sem'ânî'nin et-Tahbîr'inde yukarıdaki doğrultuda bir aktarım bulunduğunu ancak İbnü's-Sem'ânî'nin $e z-$ Zeyl'inde böyle bir bilginin bulunmadığını, İbnü's-Sem'ânî'deki bu bilginin nereden kaynaklandığını bilmediğini dahası Şehristânî'nin eserlerinin de bu bilgileri yalandığını söylemektedir. Subkî'ye göre bu bilgiler Sem'ânî'nin Tahbîr'ine sonradan sokuşturulmuştur. Aksi taktirde İbnü's- Sem'ânî'nin Zeyl'in de Şehristânî'ye yer vermemesi gerekirdi. (bk. Subkî, Tabakâtu'ş̧-Şâfi'íyyeti'l-kübrâ, tahk.: Mahmûd Muhammed Tanahi, Abdülfettah Muhammed el-Hulv, (Kahire: Matba'atü ‘Îsâ el-Bâbî el-Halebî, 1964), VI, 129-30. Madelung kendi iddiasını desteklemek için Şehristânî'nin eserlerindeki Ehli Beyt'e karşı benimsenen saygılı tavrı ve tefsirindeki bazı batıni yorumları dikkate sunmaktadır. Oysaki bu tavrı Sünni İslam'ın kendi tarihi içinde değerlendirdiğimiz de Sünniliğin genel tavrına hiç de yabancı durmamaktadır. Şehristânî'nin gerek ders aldığı Gazzâlî’nin de 
önemi sadece günümüzde değil İslam tarihi boyunca da takdir edilmiştir. Mesela, tabakat yazarı Subkî bu eseri İbn Hazm'ın hacim olarak bundan daha geniş eseriyle kıyaslayarak bu alanda yazılmış yanımda bulunan en iyi eser şeklinde nitelendirmektedir. ${ }^{5} \mathrm{Bu}$ eser haricinde Şehristânî'nin öne çıkan eserleri Sünni - Eş'arî kelamı doğrultusunda kaleme alınmış bir kelâm kitabı olan Nihâyetü'likdâm ile tamamlanamamış bir Kur'ân tefsiri çalışması olan Mefâtîhu'l-esrâr ve mesâbîhu'l-ebrâr adlı kitabı ve Meclisü'l-halk ve'lemr adlı eseridir. Bizim burada üzerinde duracağımız ve sıklıkla atıf yapacağımız eser, felsefi bir çizgide kaleme alınmış olan Musâra'atü'l-felâsife'dir.

Gerek yaşadığ1 dönemde gerekse ölümünden sonra entelektüel çevrelerce tanınan bir kişilik olarak Şehristânî İslam düşüncesi tarihinde önemli bir etkiye sahip olmuştur. Hatta onun kelâm ilmindeki etkisi bazı araştırmacılar tarafından Fahrettin er-Râzî ile birlikte değerlendirilmektedir. ${ }^{6}$ Şehristânî'nin felsefi nosyona sahip hocalardan ders aldığı ve kendisinin de felsefeyle yakın bir temas içerisinde olduğu anlaşılmaktadır. Onun felsefeye karşı yakın bir ilgisi olmakla birlikte özelde İbn Sînâ felsefesine karşı eleştirel bir tavır benimsediği görülür. $\mathrm{O}$, "sonrakilerin öncüsü ve reisi"7, "felsefede

ders arkadaşı olan Ahmed el-Havafî (ö: 1106) ve Cüveynî'nin öğrencisi olan kendisinin de 'üstadımız' diye bahsettiği Nâsır el-Ensârî (ö: 1118) gibi hocalar gerek kendisinin Sünni akidenin resmi savunucu konumundaki Nizâmiye medresesinde hocalık yapmış olması gerek onun Selçuklu Sultan ve vezirleriyle yakın bir ilişki kurması (özellikle Sultan Sencer ve veziri Muzaffer el-Mervezî ve diğer bir vezir Ali el-Musevî ile yakınlığı bilinmektedir) ve bunu sürdürmesi gerekse döneminde ve sonraki dönemde onun genel olarak konumlandırıldığı yer göz önüne alındığında onun Şii-İsmaili olduğu iddiası isabetli görünmemektedir. Şehristânî́nin Şii-İsmailî olduğu konusundaki tartışmalar için ayrıca bk. Wilferd Madelung, Toby Mayer, "Intoduction: Al-Shahrastānī, İsma'ilism and Philosophy", al-Shahrastānī, Strugling with the Philosopher, edit. and translated by Wilfred Madelung, Toby Mayer, (London: I.B. Tauris and Co. Ltd., 2001), ss. 1-15.

5 Subkî, Tabakâtu'ş-Şâfi' iyyeti'l-kübrâ, VI, 128-29.

$6 \quad$ Bk. İbrahim Medkur, fíl-Felsefeti'l-Islâmiyyeti; Menhecü ve takbikuhu, (Kahire: Dârü'l- Me'ârif, 1976), 3.bs. II, 53. Şehristânî'nin kelâm ilmindeki konumu hakkında ayrıca bk. İbn Hallikan, Vefayâtü'l-'ayân, tahk.: İhsan Abbas, (Beyrut: Dârü's-Sadr, 1978), IV, 273. Subkî, Tabakâtu'ş-Şâfi' iyyeti'l-kübrâ, VI, 129.

7 Bk. Şehristânî, el-Milel ve'n-nihal, tahk.: Ahmet Fehmi Muhammed, (Lübnan: Dârü'l-Kütübi'l-'ilmiyye, 2009), s. 444. 
Şehristânî'nin İbn Sînâ'ya Muhalefeti ve Gazzâlîci Muhalefet Taørını Dönüştürmesi zamanın allâmesi ${ }^{8 \prime \prime}$ diye bahsederek şöhret ve otoritesini öne çıkardı̆̆ı İbn Sînâ'ya karşı bu alanda müstakil bir eser yazacak kadar muhalif bir tavır içerisindedir.

Şehristânî’nin felsefeyle olan ilişkisine daha yakından baktığımızda hem bir kelâmcı hem de yetkin bir filozof olarak onun felsefi problemlerle yakından ilgilendiğini görürüz. Onun felsefeye karşı duyduğu ilgiyi bireysel bir iştiyakın yanında dönemindeki kelâm ilminde yeni başlamış olan bir eğilimin sonucu olarak da kabul edebiliriz. Nitekim yaşadığı dönem, Nîşâbûr'da Cüveynî (ö: 478/1085) ile başlatılabilecek kelam ilminde felsefi metodun benimsendiği ve felsefi konu ve problemlerin bu alandaki eserlerde ele alınmaya başlandığı bir dönemin ${ }^{9}$ hemen devamına rastlar. Nîşâbûr'da Cüveynî tarafından başlatılan bu açılım daha sonra hem Nîşâbûr'da hem de Bağdat'ta onun öğrencisi, Şehristânî'nin de çağdaşı olan Gazzâlî, yine onun bir diğer öğrencisi, Şehristânî'nin de hocası olan Nâsır elEnsâri (ö: 512/1118) ${ }^{10}$ gibi düşünürler tarafından geri dönülmeyecek bir şekilde ileri bir aşamaya taşındı. Öğrenciliğinin en önemli aşamasının Nîşâbûr'da geçtiği göz önünde bulundurulduğunda, Şehtistânî'nin de felsefi konulara kayıtsız kalması beklenemezdi. Sahip olduğu felsefi birikim ve bakışı diğer eserlerine de yansıtan Şehristânî hem İbn Sînâ felsefesine karşı eleştirilerini dile getirmek hem de felsefe alanındaki yetkinliğini ortaya koymak için müstakil bir eser olarak Musâra'atü'l-felâsife' yi kaleme almıştır. Bu eserin doğrudan felsefi alanda telif edilmiş olmasının ve büyük bir iddiaya sahip olmasının şahitliği bir tarafa, onun klasik kelâm kitapları arasında yer alan, Nihâyetü'l-ikdâm adlı eseri üzerinde yapılacak bir inceleme felsefe ile olan yakın ilgisini ortaya koymaya yeterli olacaktır.

8 Bk. Şehristânî, Musâra'atü'l-felâsife, Struggling with the Philosopher: A Refutation of Avicenna's Metaphysics, translated by Wilferd Madelung, Toby Mayer, (London, I.B.Tauris, 2001)., s. 3. (Eser Arapça aslı ile birlikte basılmış olup atıflarımız Arapça kısmadır).

9 Bk. Ömer Türker, "Eş‘arî Kelamının Kırılma Noktası: Cüveynî’nin Yöntem Eleştirileri", İslam Araştırmaları Dergisi, sy. 19, 2008, ss. 1-23.

10 Ebü'l-Kâsım el-Ensârî ismiyle meşhur olan bu âlim döneminde Nîşâbûr'un meşhur âlimlerinden biri olarak kabul edilir. el-Ensârî'nin kelâm ilmindeki hocası Cüveynî' dir. Kendisi daha sonra hocasının $e$ l-İrşad adlı eserine bir şerh yazmıştır. Subkî, el-Ensârî'nin usul, tefsir ve fikıhta üstat olarak bilindiğini ve zahitliği ile de tanındığını söyler. Bk. Subkî, Tabakâtü'ş-Şafi'iyyeti'l-kübrâ, VII, ss. 96-97. 
Musâra'atü'l-felâsife felsefi eserler arasında yer almakla birlikte klasik anlamda felsefi bir problem ya da problemlere ayrılmış kitaplardan oldukça farklıdır. Bu kitap, felsefi eserlerden aşina olduğumuz bir düzen içerisinde felsefi konuları ele alarak bu konuda açılamalar yapma şeklindeki bir yönteme sahip değildir. Her şeyden evvel eser doğrudan İbn Sînâ felsefesine yönelik eleştirel mahiyette kaleme alınmış bir çalışmadır. Bu eseri yazarken Şehristânî'yi güdüleyen duygunun felsefi bir probleme açıklık getirmek değil de felsefi bir otorite ile hesaplaşmaya girmek olduğunu söyleyebiliriz. Felsefi bir eser olarak bu kitap hem başlık hem de içerik olarak oldukça güçlü bir iddiaya sahiptir. Eserin başlığı "filozofların güreşi" ya da "filozofların mücadelesi" şeklinde Türkçeleştirildiğinde eserin içeriği ve yazarının tavrı okuyucunun zihninde daha fazla şekillenmeye başlayacaktır. Bu özelliği ile eseri Gazzâlî ile başlayan Tehâfütü'l-felâsife, el-Kitâbü'l-Mu'teber, fì Hudûsi'l-'âlem, eş-Şukûk ve şübeh 'ala'l-İşârât gibi eserlerin yer aldığı İbn Sînâ'ya yönelik felsefî eleştiri geleneğ $i^{11}$ içerisine yerleştirebiliriz. Biz burada Musâra'atü'lfelâsife' yi kendinden önce yazılmış bir başka felsefe eleştirisi olan Tehâfüt'le ve kısmen de çağdaşı olan Ebü'l-Berekât'ın el-Kitâbü'l$M u^{\prime}$ teber'i ile karşılaştırarak ele alacağız. Bu karşılaştırmaya geçmeden önce Musâra'atü'l-felâsife' de felsefi bir otorite olarak kabul edilen İbn Sînâ felsefesine yönelen eleştirilere biraz daha yakından bakmak isabetli olacaktır.

Musâra'atü'l-felâsife' de Şehristânî temelde şu beş mesele üzerinden İbn Sînâ'ya eleştiriler yöneltmektedir:

1. Mesele; varlığın kısımlandırılması konusundadır: Şehristânî bu başlık altında İbn Sînâ'nın varlığa dair yaptığı tasnifi konu edinir. O, öncelikle İbn Sînâ'nın eserlerinde varlığın sinıflandırılmastyla ilgili olarak bir kapalılık bulunduğunu iddia eder. Ona göre İbn Sînâ varlığı bazen cevher ve araz şeklinde ikilli bir ayrıma tabi tutarken bazen de zorunlu ve mümkün şeklinde bir varlık tasnifi yapmıştır. Bu başlık altında o, ayrıca iki zâtın birleşmesi konusunda İbn Sînâ'nın mantıki bir yanlışlık yaptığı, konuya (mevzu') cisim denilip denilemeyeceği, heyûlânın mahiyetinde mi yoksa varlığında mı hâle muhtaç olduğu, İbn Sînâ'nın varlığın sınıflandırılmasına

11 Bahsedilen gelenek konusunda detaylı bilgi için bk. Ayman Shihadeh, "From Ghazâlî to al-Râzî: 6th/12th Century Developments in Muslim Philosophical Theology", Arabic Science and Philosophy, vol. 15, 2005, ss. 141-79. 
Şehristânî'nin İbn Sînâ'ya Muhalefeti ve Gazzâlîci Muhalefet Taørını Dönüştürmesi dair ifadelerinde bazı eksikliklerin bulunduğu gibi başka sorunları da gündeme getirir. Bu bölümün sonunda da kendisi bir varlık tasnifi yapar. ${ }^{12}$

2. Mesele; zorunlu varlığın varlığı konusundadır: İlk bölümde varlığın sınıflandırılmasını inceledikten sonra Şehristânî kitabının ikinci, üçüncü ve dördüncü bölümü zorunlu varlıkla ilgili konulara ayırır ve İbn Sînâ'ya zorunlu varlık hakkındaki görüşleri üzerinden eleştiriler yöneltir. Bu eleştirilerinden ilki ikinci bölümde yer alır ve zorunlu varlığın varlığı konusuna odaklanır. Şehristânî'nin bu bölümde ele aldığı mesele üst başlık olarak zorunlu varlığın varlığı olmakla birlikte onun bu meseleyi daha çok İbn Sînâ'nın varlığı kavrayış tarzı üzerinden ele aldığı görülür. Bu noktada onun temel iddiası İbn Sînâ'nın varlığı cins ya da tür hükmünde genel bir kavram olarak tasavvur ettiği şeklindedir. Bu bölümde ayrıca varlığın müşekkek ve mutavatı şeklinde ikili bir ayrımla ele alınamayacağı, zorunlu varlıkta varlık ve zorunluluğun ayrıştırılıp ayrıştırılamayacağı, "zorunlu varlık" ifadesindeki terimlerden her birinin ayrı bir varlığı ya da bir varlıktaki farklı yönlere işaret edip etmediği gibi problemler hakkında da eleştiriler yapılmaktadır. ${ }^{13}$

3. Mesele; zorunlu varlığın birliği konusundadır: Bu başlık altında İslam düşüncesi tarihinde deki çok temel bir problem merkeze alınmaktadır. Burada zorunlu varlığın birliğinin yanında bu Bir'den çokluğun nasıl çıktığı sorunu bağlamında üretilen cevap üzerinden Şehristânî, İbn Sînâ'ya eleştiriler yöneltmektedir. Bilhassa İbn Sînâ'nın zorunlu varlığın birliği konusundaki sözleri ve bir yaratma biçimi olarak filozofun benimsediği sudûr teorisi hakkında Şehristânî eleştirilerini ortaya koyar. ${ }^{14}$

4. Mesele; zorunlu varlığın bilgisi konusundadır: Bu mesele Musâra' $a^{\prime}$ da yer alan doğrudan zorunlu varlıkla ilgili olan eleştirilerin sonuncusudur. İslam felsefesi tarihinde filozoflara yöneltilen eleştirilerde gündeme getirilen bu meşhur konuya Şehristânî eserinde dördüncü sıradan yer vermektedir. Burada o, filozofların Tanrı'nın bilgisine dair Aristoteles'ten beri temel hareket noktalarından biri olan O'nun aynı zamanda hem akıl hem akleden ve hem

12 Bk. Şehristânî, Musâra'atü'l-felâsife, ss. 7-23.

13 Bk. Şehristânî, Musâra'atü'l-felâsife, ss. 24-42.

14 Bk. Şehristânî, Musâra'atü'l-felâsife, ss. 43-66. 
de akledilen olarak kabul edilmesinden yola çıkmakta sonra da O'nun akletmesinin, yaratma anlamına gelip gelmeyeceği meselesine geçmektedir. Yine Tanrı'nın bilgisinin tümel bir tarzda olup olamayacağı bu bilginin tikelleri nasıl kapsadığı da burada eleştiri konusu edilen diğer meselelerdir. ${ }^{15}$

5. Mesele; âlemin sonradan yaratılmışlığı konusundadır: Şehristânî'nin söz konusu eserinde müstakil olarak ele aldığı ve eleştiriler yönelttiği son mesele Gazzâlî'nin Tehâfüt'te birinci mesele olarak incelediği ve kendisine eser içerisinde en geniş yeri ayırdığ 1 âlemin kıdemi meselesidir. Bu sorunun incelenmesi bağlaminda "öncelik", "sonralık" ve "birliktelik" gibi kelimelerin anlamı üzerinde durulup sonra da "varlık" ve "devam" lafızlarının aynı anlamda kabul edilmesi gerektiğinden bahsedilir. Bunun devamında da Şehristânî, İbn Sînâ'nın âlemin kıdemi konusundaki dört farklı delilini tek tek alarak bunlara yönelik eleştirilerini sıralar ve bölümün sonunda da her bölümde olduğu gibi konu hakkındaki kendi görüşlerine yer verir. ${ }^{16}$

\section{Gazzâlî̀'den Şehristânî'ye İbn Sînâ Eleştirilerindeki Süreklilik ve Dönüşüm}

İslam düşüncesinde İbn Sînâ felsefesine karşı öne çıkan muhalif tavra baktığımızda bu eleştirel eserlerin kaleme alındıkları dönem dikkat çekicidir. Gazzâlî'nin Tehâfüt'ü ile başlatılabilecek bu döneme baktığımızda muhalif ve eleştirel tarzda yazılan eserlerin başlangıcının Büveyhîler döneminde önce Mu'tezilî kelamcılar eliyle daha sonra da felasifenin katkılarıyla doruk noktasına ulaşan akılcı bir hareket sonrası döneme rastladığı görülür. Bu eleştirel tavrı ortaya çıkaran ve geliştiren ise daha büyük bir projenin entelektüel alana yansıyan uzantısıdır. Bu proje, bilhassa Selçuklu Sultanı Alparslan'ın Mu'tezilî akideyi benimseyen vezir Kündürî'yi azli ve Nizamülmülk'ü bu makama tayiniyle başlatılabilecek bölgenin Sünnileştirilme çalışmasıdır. İslam düşüncesi içerisinde $\mathrm{Mu}$ 'tezilî hareketin tarihsel seyrine baktığımızda Büveyhîler döneminin Mu'tezilî düşünce için yeniden bir toparlanma ve canlanma dönemi olduğunu görürüz. Büveyhîlerle başlayan bu canlanma Selçukluların ilk döneminde bilhassa Tuğrul Bey ve veziri Kündürî zamanında

15 Bk. Şehristânî, Musâra'atü'l-felâsife, ss. 67-92.

16 Bk. Şehristânî, Musâra'atü'l-felâsife, ss. 93-118. 
devam etmiş ve en ileri seviyesine ulaşmıştır. Ancak Sultan Alparslan'ın tahta geçmesi ve politikalarından rahatsız olduğu anlaşılan Tuğrul Bey döneminden beri vezirlik yapan Kündiri'yi azledip yerine Nizamülmülk'ü ataması sonucu bölgedeki entelektüel faaliyet farklı bir istikamete ve yeni bir paradigma kurmaya doğru yönelmiştir. Yeni devrede sadece bir önceki dönemde bu bölgeden uzaklaştırılan ya da terk etmek zorunda kalan Şâfî-Eş'ârî âlimlerin geri dönüşlerinin sağlanmasıyla kalınmamış ayrıca devletin resmi politikası da bu doğrultuda yeniden güncellenmiştir. Bu noktada yeni devrin din politikası doğrultusunda kurulan Nizamiye medreseleri aracılığıyla Sünni - Eş'arî - Şâfî düşünce topluma ortak payda olarak

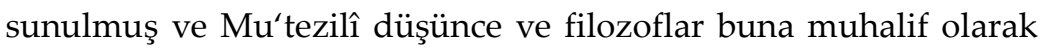
görülmüştür. ${ }^{17} \mathrm{Bu}$ dönemde Sünniliğin öne çıkarılması noktasında Bâtıniliğin o günkü tahripkâr etkisi de kesinlikle gözden uzak tutulmamalıdır. İşte böylesi bir paradigmanın kuruluş devrinde ve devamında felsefeye ve özellikle de İbn Sînâ felsefesine yönelik eleştirel bir tavrın yükseldiği görülmektedir. Ancak bu tavır, burada da ortaya koymaya çalışacağımız gibi, Gazzâlî’nin başlattığı istikamette devam etmeyecektir. Şimdi İbn Sînâ felsefesine eleştirel olarak yaklaşan eserlere Musâra'atü'l-felâsife'yi merkeze alarak daha yakından bakmaya çalışalım.

Musâra'atü'l-felâsife ve Tehâfütü'l-felâsife arasında bir değerlendirme yapabilmek için öncelikle bu eserin yazılış tarihi üzerinde durmamız gerekmektedir. Ancak Musâra'a'nın yazılış tarihini elimizdeki mevcut bilgilerden hareketle tam olarak tespit etmek mümkün olmamaktadır. Bu konudaki bilgimiz, eserin Tirmiz'de yazıldı̆̆ı ve Şehristânî'nin olgunluk hatta son dönem eserleri arasında yer aldığıdır. Yazarının hayat hikâyesine baktığımızda, büyük bir ihtimalle Şehristânî'nin 1141 yılında Karahıtaylara karşı Selçukluların kaybettiği Katvan savaşına kadar Merv'de yakın çevresi arasında yer aldığı Sultan Sencer'in yanında kaldığı kabul edilebilir. Onun daha sonra buradan ayrılarak Tirmize geçtiği ve orada nakibü'l-eşrâf olan Ali el-Mûsevî'nin hizmetine girdiği kabul edilmektedir. Nitekim söz konusu eseri bu vezire takdim ettiği

17 Hanefi-Mu'tezilîlerin bahsedilen bu dönemdeki yeniden yükselişi ve ŞâfîEş'arîliğin bundan etkilenmesi konusundaki bir çalışma için bk. Ömer Ali Yıldırım, "Mutezile ve Nîşâbûr Fitnesi: Mihnetü Eşấ'ire", Din Felsefesi Açısından Mutezile Gelen-Ek-i, Klasik ve Çağdaş Metinler Seçkisi (II), Der. Recep Alpyağıl, (İstanbul: İz yay. 2014), ss. 696-713. 
bilinmektedir. Şehristânî'nin 1153'te doğum yeri olan Şehristân'da öldüğü bilinmekle birlikte Tirmiz' de ne kadar kaldığ bilinmemektedir. Tehâfütü'l-felâsife' ye gelince, Gazzâlî'nin bu eserini Bağdat Nizamiyesinde hocalık yaparken 1095 yılında yazdı̆̆ 1 bilinmektedir. ${ }^{18}$ Bu durumda her iki eser arasında kesin bir rakam verilememekle birlikte yaklaşık elli yıllık bir süre olduğu söylenebilir.

Eleştirel bir felsefi tavrı benimseyen bu eserlerin ortak bir üslubu ya da kendi içlerinde benimsedikleri bir tarz var mıdır? Eserlere bu yönden baktığımızda onların benimsediği ortak bir tavrın olmadığını görürüz. Dolayısıyla bu eserler bir birlerinden çeşitli yönlerden farklılaştıkları gibi Musâra'atü'l-felâsife de Tehâfütü'lfelâsife' den çeşitli yönlerden ayrılır.

Öncelikle, Şehristânî bu eserde felsefeyi, felsefi tavrı ya da metodu değil doğrudan İbn Sînâ'nın şahsını hedef almaktadır. Bunu da eserin giriş kısmında o, açık bir şekilde ifade eder. Şu ifadeler onun tavrını anlama noktasında fikir verici olacaktır:

Felsefi ilimlerde öne çıkan ve döneminin en bilgesi olan kişinin Ebû Ali el-Hüseyin Abdullah b. Sînâ olduğu, çok çabalasa dahi hiç kimsenin onun seviyesine yetişemeyeceği, en iyi araçları kullansa bile onun ulaştıklarına ulaşamayacağı konusunda görüş birliği vardır. Onlar, İbn Sînâ'nın sözlerini derinlemesine anlayan ve onun felsefesindeki örtük haldeki noktaları bilenin en yüksek kazancı elde eden ve yüce ereğe ulaşan kişi olacağı konusunda görüş birliğine vardılar. [Benzer şekilde (çev.)] Kabul etmeyerek ve hatalı görerek ona karşı çıkmanın ve onun sözlerini geçersiz kılmak ve eleştirmek amaciyla ele almanın ahmaklık olduğu konusunda da görüş birliğine vardılar...

Ben onunla kahramanca bir güreşe tutuşmak ve onu sıradan insanlar seviyesine indirmek istedim. ${ }^{19}$

Bu ifadeler açık bir şekilde Şehristânî'nin temel gayesinin, İbn Sînâ felsefesinin içsel tutarsızlığını sorgulamak ya da onun felsefesindeki yanlışları ortaya koyarak insanları hatadan uzaklaştırmak olmayıp doğrudan İbn Sînâ'nın entelektüel çevre içerisindeki otoritesini hedef almakta olduğunu göstermektedir. Bu durum bize aynı

18 Bk. George F. Hourani, "The Chronology of Ghazali's Writings", Journal of American Oriental Society, vol. 79, issue, 4 (Ekim- Aralık) 1959, s. 225-233; Mahmut Kaya, "Tehâfütü'l-felâsife”, DİA, c. 40, ss. 313-14. 
zamanda Gazzâlî̀nin Tehâfüt'ünün yazıldı̆̆ı dönemden Şehristânî'nin Musâra'a' sına kadar geçen sürede entelektüel alanda İbn Sînâ'nın otoritesinin gücü konusunda olumsuz bir değişiklik olmadığını da göstermektedir. Nitekim Gazzâlî de Tehâfüt'ün hemen başında İbn Sînâ'yı -Fârâbî ile birlikte- İslam felsefesinin en önemli iki otoritesinden biri olarak kabul etmekte ve filozoflara yönelik eleştirilerini bu filozoflar üzerinden yapmaktaydı. ${ }^{20}$ Ancak Gazzâlî de açık bir şekilde İbn Sînâ'yı felsefi bir otorite olarak kabul ederken onun eleştirileri İbn Sînâ'nın bu felsefi otoritesine karşı değildir. O, İbn Sînâ'nın felsefi otoritesini sarsmak yerine dini kaygıların da açı bir şekilde etkisiyle felsefenin entelektüel kesimdeki etkisini hedef almaktadir.

Musâra'atü'l-felâsife felsefi bir eser olarak bünyesinde analitik bir felsefi dil ve eleştiri barındırmaktadır; bu yönü iledir ki eseri İslam felsefesi tarihinde aralarında Gazzâlî'nin Tehâfüt'ünün de yer aldığı felsefe eleştirisi geleneği içerisinde değerlendiriyoruz. Bununla birlikte, bu eser, yukarıda dikkat çekilen yönlere ek olarak gerek dil gerekse de metot ve muhteva bakımından Gazzâlî'nin Tehâfüt'ünden farklılaşır. Eserde dil olarak belki de hitap ettiği kesimden dolayı -Şehristânî bu grubu "yüce meclis" diye niteler- yüksek bir düzeyde analitik ve teknik bir dil kullanıldı̆̆ı görülür. Burada tartışma ortamının "yüce meclis" (el-meclisü'l-'âlî) olarak belirtilmesi ayrıca bir önemi haizdir. Nitekim ifade, eserin hitap ettiği kitleyi nitelemektedir. Öyle ise Şehristânî eserini, filozofların eserleri hakkında hüküm verebilecek bir meclise -ister hali hazır döneme isterse de geleceğe yönelik bir gönderme olsun- yönelik yazmaktadır. Bir diğer ifade ile Şehristânî doğrudan felsefe alanına yönelik bir eser kaleme almıştır.

Metot olarak ise gerek Tehâfüt gerekse de Musâra'a karşı tarafın görüşleri arasındaki çelişkiyi ortaya koyma şeklinde bir yol izlemede ortaklık etseler de sahip oldukları amaç hususunda farklılaşmaktadirlar.

Muhteva olarak baktığımızda ise iki eser arasında ciddi bir fark olduğu görülür. Eser içerik olarak Tehâfüt ile karşılaştırıldığında daha sınırlıdır. Şehristânî eserin girişinde filozoflara yönelik eleştiri için mantık, doğa bilimleri ve metafizik alanındaki yetmiş mesele

20 Bk. Gazzâlî, Tehâfütü'l-felâsife, haz.: Maurice Bouyges, (Beyrouth: Imprimerie Catholique, 1927), s. 9. 
içerisinden yedi mesele belirlediğini söylemektedir. Bu problemlerin tamamı da, az yukarıda görüldüğü gibi, metafizik konularıyla ilgilidir ancak bunlardan da beş tanesi eserde ele alınarak incelenir. Diğer iki mesele ise Şehristânî'nin ifadesiyle bazı zorunluluklar yüzenden terk edilmiştir. Kitabın başında, terk edilmek zorunda kalınan iki meseleden birinin mebâdîler diğerinin de şüpheli meseleler hakkında olacağından bahsedilmektedir. Ancak beşinci meselenin sonuna ulaştığında yazar bize kendisini üzüntüye boğan zamanın fitnesi ve yeni ortaya çıkan bazı olumsuz hadiselerle uğraşmaktan dolayı bu konuları ele alamadığını söyleyerek mazeret bildirir. Bu meseleleri ele almak yerine karmaşık ve şüpheli gördüğü bazı problemleri zikretmekle yetinir.

Tehâfüt'teki eleştiri noktaları ise doğa bilimleri (özellikle psikoloji) ve metafiziği kapsamaktadır. ${ }^{21} \mathrm{Bu}$ konularda Gazzâlî yirmi problem üzerinden eserini kurgular ve her bir problemi de geniş bir tarzda ele alır. Musâra' $a^{\prime}$ da ise doğrudan metafizik konulara yoğunlaşılmakta doğa bilimleri konularına ise değinilmemektedir. Yine Tehâfüt'te Gazzâlî́nin belki de avam için önemli gördüğü mucize ve bedenlerin yeniden diriltilmesi konularına müstakil bölümler açılırken Şehristânî’nin bu konulara ilgisiz kaldığg görülmektedir.

Eserler metot ve üslup yönünden farklı bir değerlendirmeye tabi tutulduğunda Musâra'a'nın daha pür bir felsefi kaygı barındırdığını ve bu yönüyle de Tehâfüt'teki eleştiri biçiminden farklılaştığını söyleyebiliriz. Şehristânî'nin kitabın giriş bölümünde zikrettiği ilkelere sadık kalarak, felsefi düşünme tarzı içerisinde hareket ettiğini söyleyebiliriz. Bunlardan hareketle de onun, Gazzâlî́nin yer yer dini kaygıların da belirleyici olduğuna şahitlik ettiğimiz ${ }^{22}$ tutu-

21 Felsefenin bir ilimler sistemi olarak kabul edildiği dönemde Gazzâlî́nin mantığ1 felsefeden ayrı olarak ele alması, psikoloji, metafizik gibi konuları da ayrı ayrı değerlendirmesine dikkat çeken bir araştırma için bk. Fatih Toktaş, İslam Düş̧üncesinde Felsefe Eleştirileri, (İstanbul, Klasik yay.), 2004. s. 2.

22 Gazzâlî'nin eleştirilerinin arka planını ve onu güdeleyen motivasyonu görmek için Tehâfüt'ün hemen başındaki ifadelerine ayrıca da Munkız'a bakılabilir. Buralardaki ifadeleri bize Gazzâlî'nin eleştirilerinin nedenli dini-toplumsal bir kayg1 ile yapıldığını göstermektedir. Örnek olarak burada şu ifadeleri dikkate sunuyoruz: Akran ve arkadaşlarından anlayış ve zekâ üstünlüğ̈̈ ile ayrıldığına inanan bir gurup insan gördüm. Bunlar İslâm'ın ibadet görevlerini terk ediyor, namaz, yasaklardan sakınmak gibi dini görevleri küçümsüyor, şeriatın ibadetlerini ve sınırlarını yanlış değer- 
Şehristânî'nin İbn Sînâ'ya Muhalefeti ve Gazzâlîci Muhalefet Taørını Dönüştürmesi mundan uzak bir biçimde daha pür bir felsefi eleştiriye doğru evirildiğini kabul edebiliriz. $\mathrm{O}$, eserin girişinde nasıl bir yol izleyeceğini şöyle taahhüt etmektedir:

Kendime şunu şart koştum: Onu [İbn Sînâ'yı] sanatının d1şında değerlendirmeyeceğim. Manası ve hakikati üzerinde anlaştı̆̆ımız kavramlar konusunda onunla inatlaşmayacağım. Cedelci bir kelâmcı ya da inatçı bir sofist olmayacağım. Bundan dolayıdır ki onun kitaplarındaki lafız ve mana olarak bulunan çelişkileri açıklamakla başlayacağım ve ispat metinlerindeki madde ve sûret olarak bulunan hataları ortaya çıkarmakla tamamlayacağım. ${ }^{23}$

$\mathrm{Bu}$ taahhütten sonra Musâra'a'da izlenen tavır ve benimsenen tutuma baktığımızda ele alınan konuların toplumsal alandaki tezahürleri itibari ile değil de salt kendi anlam dünyası içerisinde kalınmaya gayret edilerek bir değerlendirme ve eleştiriye tâbi tutulmakta olduğunu görürüz. Bu yönüyle de eserde güdülen felsefi kaygının daha baskın olduğu, içerik ve kapsam olarak Tehâfüt'ten daha sınırlı olmasına karşın felsefi dil ve kaygıları barındırma konusunda daha ileri bir seviyede olduğu söylenebilir.

Musâra'a'yı Tehâfüt'ten ayırarak onu daha özel kılan en önemli hususlardan biri de eserde sadece konu hakkındaki İbn Sînâ'nın düşüncelerini, bunlar arasında uzlaştırılması zor görünen yönleri ve bunlara yönelik eleştirileri sıralamakla yetinilmemesidir. Şehristânî, İbn Sînâ felsefesinde bulunduğunu iddia ettiği meselelerle ilgili çelişkileri dile getirip eleştirilerini sıraladıktan sonra her bölümün sonuna "Tercih Edilen Görüş" ya da "Doğru Olan Kabul" gibi başlıklar ekleyerek kendisinin konu hakkındaki görüşlerine uzun ve detaylı olmasa da yer verir. Bu, eleştirilerin daha ziyade "yıkıc1" bir tarzda olduğu ifade edilen ${ }^{24}$ Tehâfüt'te bulunmayan önemli bir özelliktir. Nitekim Gazzâlî Tehâfüt'te filozoflara karşı eleştiriler getirmekte ve onların teorilerinin geçersizliğini farklı yönlerden ortaya koymaya gayret etmektedir. O, bunu yaparken bu konuda gerçekte olması gereken felsefi teorinin veya tutarlı olan görüşün ne olduğu

lendiriyorlar. Onun "dur" dediği yerde ve sinırlarında durmuyorlar bilakis birtakım zanlara uyarak din bağından tamamıyla çıkıyorlar. Bk. Gazzâlî, Tehâfütü'l-felâsife, s. 4. Ayıca bk. Age, s. 13, 14. Konu hakkında ayrıca bk. Ömer Ali Yıldırım, Şehristân'̂nin İbn Sînâ Eleştirisi, (İstanbul: Litera yay. 2016), s. 51.

23 Bk. Şehristânî, Musara'âtü'l-felâsife, ss. 3-4.

24 Fatih Toktaş, İslam Düşüncesinde Felsefe Eleştirileri, (İstanbul: Klasik), 2004, s. 1. 
konusuna girmez. Şehristânî ise kendisi de bir filozof olarak, okura konu hakkındaki görüşlerini öğrenme imkânı sunmaktadır. Bu da onun düşüncesindeki felsefi karakterin belirleyici etkisinin bir diğer göstergesi olarak kabul edilebilir. ${ }^{25}$ Eserin bu özelliğinden dolayı, önceki bir çalışmamızda bu durumun bize Şehristânî'nin amacının felsefî düşünceyi mahkûm etmek ya da yıkmak olmayıp, daha pür bir felsefeye ulaşma ya da hakikate felsefi bir yoldan ulaşma konusunda atılmış bir adım olduğunu söyleme imkânı verdiğini belirtmiştik. ${ }^{26}$ Nitekim filozofun kendisi de bu kitabı kaleme almadaki amacının, yüce meclis huzurunda bir filozofun diğer bir filozofa üstünlügünü göstermek olduğunu vurgulamaktadır. Burada ise şunu ilave edelim ki, aslında Şehristânî'nin bu eserdeki amacı döneminin tartışmasız en yüksek felsefi otoritesi olarak kabul edilen bir filozofun otoritesini sorgulamaktır. Bu sorgulama neticesinde bir taraftan İbn Sînâ bulunduğu yüksek konumdan indirilecek diğer taraftan da kendisinin de yetkin bir felsefi otorite olduğu onaylanmış olacaktır. $\mathrm{Bu}$ amaçladır ki o, eserine yetmiş adet problem arasından seçtiğini söylediği yedi adet metafizikle ilgili meseleyi almıştır. Burada problemlerin metafizik alanından seçilmiş olması özellikle bilinçli bir tercihtir. Nitekim metafizik hem felsefenin en ileri konularının işlendiği bir alan hem de bir filozofun yetkinliğini ve felsefi ustalığını en ileri düzeyde ortaya koyduğu bir saha olarak kabul ediliyordu. İncelenen konular bu alandan seçilmekle İbn Sînâ' nın bir filozof olarak en yetkin olduğu alandan konular seçilmiş olmakta, onun bu alandaki yetersizliği ortaya konularak aslında entelektüel çevreler tarafından kabul gördüğü şekilde yetkin bir filozof olmadığı ortaya konulmaya çalışılmaktadır. Diğer taraftan da bu en ileri seviyedeki felsefi görüşlerin geçersizliği ortaya konulduktan sonra kendisi bu alanda olması gereken teoriyi ortaya koyarak eleştirdiği filozofun konumuna geçmiş olmaktadır. Her ne kadar kendisi amacının İbn Sînâ'yı bulunduğu yüksek alandan indirmek olduğunu söylese de İbn Sînâ bu konumdan indirildiğinde doğal bir şekilde kendi felsefesi ya da ortaya koyduğu görüşlerle o yüce konumun namzedi haline gelecektir. Böyle bir tavır ya da amaç ise Gazzâlî'nin eserinde görülmez. Bir diğer ifadeyle Gazzâlî́nin felsefi bir otorite olmak gibi bir iddiası ya da amacı yoktur. $\mathrm{O}$, yeni bir felsefe kurmak yerine belirlediği konularda filozofların top yekûn otoritesini sarsmayı hedef

25 Bk. Yıldırım, Şehristânı̂'nin İbn Sînâ Eleştirisi, ss. 51-52.

26 Bk. Yıldırım, Şehristânî̀nin İbn Sînâ Eleştirisi, s. 52. 

almaktadır. Nitekim Gazzâlı̂'nin ele aldığı bu metafizik konular hakkında en temel iddiası bu konularda tutarlı bir felsefi teorinin ortaya konulabileceğini kabul etmemesine dayanmaktadır. Hatta onun amacının böyle bir teorinin olamayacağını ortaya koymak olduğu söylenilebilir. Bundan dolayı da Gazzâlî́den bu doğrultuda yeni bir felsefi teoriyi ortaya koyması beklenemezdi de.

Şehristânî'nin tavrını süreç içerisinde değerlendirdiğimizde ise burada Gazzâlî́nin tekfirle noktalanan değerlendirme ve eleştirilerinin sonraki dönemde daha makul bir yöne doğru evirildiği ilk elden gözlemlenebilecektir. Nitekim Şehristânî, Gazzâlî̀'den farklılaşarak ele aldığ 1 problemlerin incelenmesinden sonra bu konuda filozoflar "küfre düşmüştür", "bidate girmiştir" vs. hükümler vermemektedir. Bunun yerine o, İbn Sînâ'da bulunduğunu iddia ettiği çelişkilerden bahsettikten sonra bu konudaki gerçek bilginin ne olması gerektiğine dair kendi görüşlerine geçmektedir. İşte bu noktada bu sürecin salt tenkitten alternatif geliştirmeye doğru evirildiğini söyleyebiliriz. Sürecin bu aşamasında düşünürler, filozofların görüşlerindeki çelişki ve tutarsızlıklardan hareketle eleştiri getirmekle yetinmemekte, kendileri de alternatifler sunarak hem konunun gelişimine hem de felsefi üretime doğrudan katkı sunmaktadırlar. Bu durum yukarıda Musâra'a' yı da aralarına kattığımız eserlerden takip edilebileceği gibi Şihâbüddîn Sühreverdî'nin (ö: 587/1190) felsefesinde daha açık bir şekilde görülebilir. Nitekim Sühreverdî'nin Meşşâî felsefe ve İbn Sînâ'ya karşı olan eleştirileri sadece sistem içi yeni fikir ya da teori üretme düzeyinde de kalmayıp bunu da aşarak yeni bir felsefi kurguya ulaşmakta olduğu görülmektedir. ${ }^{27}$

Şehristânî'nin eserini Gazzâlî’nin Tehâfüt'ünden yaklaşık elli yıl gibi bir süre sonra yazdığına değinmiştik. Burada Şehristânî'nin bu esere karşı tavrına baktığımızda ilginç bir tutumla karşı karşıya geliriz. Şehristânî eserinin hiçbir yerinde ne Gazzâlî̀ye ne de eserine atıf yapar. Onun bu tavrı ilk başta Gazzâlî́nin eserinden haberi yokmuş gibi bir izlenim vermektedir. Ancak bazı verileri değerlendirdiğimizde onun Gazzâlî̀den ve çalışmalarından haberdar olmamasının mümkün olmadığını görürüz. Öncelikle Şehristânî'nin hocalarından bazıları Gazzâlî’nin de hocası olan Cüveynî'nin öğrencisidir. Özellikle Şehristânî'nin üstadımız diye

27 Bk. Tahir Uluç, Sühreverdî'nin İbn Sînâ Eleştirisi, (İstanbul: İnsan yay., 2012), s. 8. 
bahsettiği kendisinden kelâm ve cedel okuduğu Ebû Kasım elEnsârî'nin Cüveynî'nin öğrencisi olması Gazzâlî ve Şehristânî arasındaki uzaktan kurulabilecek ilişki noktalarından biridir. Her iki müellif arasındaki ortak noktalardan bir diğeri de Ahmet elHavâfí'dir (ö: 500/1106). El-Havâfî hem Gazzâlî'nin ders arkadaşı hem de Şehristânî'nin kendisinden fıkıh dersleri aldığı bir âlimdir. Bu iki filozof arasındaki ortak noktaların bir diğeri de hem Nîşâbûr hem de Bağdat Nizamiye medreseleridir. Öncelikle Nişâbûr'a baktığımızda bu şehir Şehristânı̂’nin öğrenciliğinin geçtiği şehirdir. O, bu şehirde yukarıda isimlerinden bahsettiğimiz hocalara ek olarak Ahmet el-Medenî'den (ö: 490/1096) hadis okumuştur. El-Medenî'nin ölüm tarihini göz önüne aldığımızda Şehristânî'nin 1096 tarihinden önce Nişâbûr'da bulunmuş olması gerekir. Gazzâlî̀nin ise bu şehri hocası Cüveynî'nin ölümünden (1085) sonra terk ettiğini biliyoruz. Bu durumda Şehristânî en geç Gazzâlî' den on bir yıl sonra bu şehre gelmiştir. Bu tarihin daha da erken olması muhtemeldir. $\mathrm{Bu}$ durumda onun aynı medresede ders alan bir kişiyi en azından ismen duymuş olması büyük bir ihtimaldir. Gazzâlî'nin henüz Cüveynî' nin medresesinde iken hem zekâ ve bilgisiyle öne çıkması ayrıca da Nizâmülmülk gibi siyasilerle ilişkisi olması, Nişâbûr'dan ayrıldıktan birkaç yıl sonra Bağdat Nizâmiyesi gibi dönemin önde gelen bir ilim merkezinin başına geçmesi itibariyle şöhret ve etkinliği artan bir isim olması bu ihtimali daha da kuvvetlendirmektedir. Bu iki filozof arasındaki bir diğer ortak nokta da Bağdat Nizamiye medresesidir. Şehristânî'nin 1116 yılında hac dönüşünde bu şehre geldiği ve burada üç yıl kadar kaldığı bu süre içerisinde Bağdat Nizâmiye medresesinde dersler verdiği bilinmektedir. ${ }^{28}$ Bağdat Nizâmiye medresesi aynı zamanda Gazzâlî'nin 1090-95 yılları arasında hocalık yaptığı ve aralarında Makâsıdu'l-felâsife ve Tehâfütü'lfelâsife gibi eserlerini yazdığı yerdir. Gazzâlî́nin bu medreseden 1095 yılında ayrıldığı bilinmektedir. Bu durumda Şehristânî Gazzâlî̀'den yaklaşık yirmi bir yıl sonra aynı medresede hocalık yaptığı anlaşılmaktadır. Onun hocalık yaptığı tarihte Gâzzâlî́nin ölümü üzerinden yaklaşık beş yıl geçmiştir. Bu durumda Şehristânî'nin böylesi ortak noktaları olduğu bu isimden ve eserlerinden haberdar olmaması mümkün görünmemektedir. Bize

Bk. Subkî, Tabakâtü'ş-Şâfi'iyyeti'l-kübrâ, c. VI, s. 129. 
Şehristânî'nin İbn Sînâ'ya Muhalefeti ve Gazzâlîci Muhalefet Taørını Dönüştürmesi Şehristânî'nin Gazzâlî’yi tanıdığına dair en güçlü aktarım ise çağdaşı olan Beyhakî’den (ö: 565/1169) gelmektedir. O, Târîhu hükemâi'lİslâm'da şöyle bir olayı nakleder:

[Şehristânî] Tefsir yazıyor ve ayetleri şeriat, felsefe (hikmet) ve diğer şeyler doğrultusunda te' vil ediyordu. Ona dedim ki: Bu doğru bir şey değil. Kur'an ancak selef-i salihin ve tabiinin sözleri ile yorumlanabilir. Felsefe, Kur'an tefsiri ve te'vilinden başka bir şeydir... Şeriat ve felsefe arasını İmam Gazzâlî’den daha güzel kimse birleştirmedi. Bunun üzerine sinirlendi. ${ }^{29}$

Burada nakledilen olay bize Şehristânî'nin Gazzâlî̀'den ve eserlerinden haberdar olduğunu açık bir şekilde göstermektedir. Şehristânî'nin Gazzâlî’den ve eserlerinden haberdar olmasına rağmen ondan bahsetmemesi ilginçtir. İlginç olan bir diğer nokta da Musâra' $a^{\prime}$ da Şehristânî'nin israrla Tehafüt'ten farklılaşmaya çalışmasıdır. Öyle ki benzer problemlerin ele alındığı yerde Şehristânî o problemin Gazzâlî’nin ele aldığı yönünden farklı bir boyutunu gündeme taşıyarak ondan farklılaşmaya çalışmaktadır. Biz, bu tavrı onun Gazzâlî'nin Tehâfüt'te filozoflara karşı benimsediği tavırdan duyduğu rahatsızlığın neticesi olarak da kabul edebiliriz. O, bu tavrıyla bir taraftan 1srarla Gazzâlî̀'den farklılaşırken diğer taraftan da Gazzâlî'nin temsil ettiği, filozofları yer yer mahkûm etmeye ve tekfire varan eleştiri çizgisine karşı eleştirel bir tavır sergilemiş olmaktadır. Nitekim onun eserinin hiçbir yerinde İbn Sînâ'yı tekfirle itham etmediğini ayrıca kendisi ele aldığı problemlerin sonunda şahsi görüşlerini ortaya koyarak bir felsefeyi diğer bir felsefe ile aşma tavrını öne çıkarmayı amaçladığını söylemiştik.

\section{Sonuç}

Çalışmada görüldü ki, Şehristânî'nin Musâra'atü'l-felâsife adlı eserindeki felsefe eleştirileri onun genel anlamdaki bir felsefe karşıtlı̆̆ının sonucu değil, bundan ziyade İbn Sînâ'nın otoritesine karşı muhalefetinin sonucudur. Onun bu tavrının amacı ise bir taraftan İbn Sînâ'nın entelektüel alandaki otoritesini sarsmak iken diğer taraftan da kendinin felsefi bir otorite olduğunu ispat etmektir.

Musâra'atü'l-felâsife Gazzâlî'nin Tehâfütü'l-felâsife'sinden sonra yazılmış olmakla birlikte amaç, yöntem ve üslup olarak onu devam

29 Bk. Beyhakî, Târîhu hukemâ'i'l-İslâm, tahk. Memduh Hasan Muhammed, (Kahire, Mektebetü's-Sekâfeti'd-Diniyye, 1996), s. 162. 
ettirmemiş ve kendisi bu noktada yeni bir yol benimsemiştir. Musâr' $a^{\prime}$ nın benimsediği bu yol gerek İbn Sînâ nezdindeki felsefe eleştirilerini gerekse de genel anlamda felsefe ve filozoflara yöneltilen eleştirileri salt bir felsefe karşıtlığ 1 şeklindeki dar ve hasmane bir üslup ve sınırdan alıp, bunu alternatif üreterek eleştirilen bir felsefeyi bazen sistem içi bir müdahale ile restore etme şeklinde bazen de başka bir felsefe ile aşma denemesi şeklinde ifade edilebilecek bir doğrultuya yönlendirmiştir. Aralarındaki irtibat her ne kadar belirgin olmasa da bu durum hem Ebü'l-Berekât'in el-Kitâbü'l-Mu'teber'inden hem de Sühreverdî'nin çalışmalarından takip edilebilir. Nitekim belirtilen bu filozofların çalışmalarının kesinlikle Gazzâlîci bir çizgide olmayıp Şehristânî'nin eserinde temsil edilen alternatif üretme şeklindeki yolu benimsemesi bizi bu sonuca götürmektedir.

Gazzâlî'nin Tehâfüt'ünün sonraki dönemde felsefe eleştirileri içerisinde yalnızlaşmasını bu eserin yazıldığı dönemde resmi devlet projesi ürünü olarak ortaya çıkmasıyla izah edebiliriz. Bu durum, Selçuklu Sultanı Alparslan ve Melikşâh'ın veziri Nizâmülmülk'ün, Selçuklulardan önce bölgenin hâkimi olan Büveyhîler döneminde güçlendiği görülen Bâtınîliği zayıflatmak amacıyla başlattığı yeni projede akılcı Hanefi-Mu'tezilî düşünceye karşı Şâfî-Eş’ârî düşünceyi öne çıkarmasıyla ilgilidir. Nitekim Gazzâlî, yakın çevresi arasında yer aldığı Nizâmülmülk'ün bu projenin uzantısı olarak kurduğu Nizâmiye medreselerinden olan Bağdat Nizâmiyesinde dersler vermiş ve felsefeye yönelik eserlerini de bu medresedeki hocalığı döneminde kaleme almıştır. Nizâmülmülk'ün başlattığı proje bölgede başarılı olmasına rağmen Gazzâlî'nin Tehâfüt'teki tavrı felsefe eleştirileri barındırdığını söylediğimiz yukarıdaki eserlerde devam ettirilmemiştir.

Son olarak, Sehristânî'nin Musâra'a'da Gazzâlî'den ve eseri Tehâfüt'ten hiç bahsetmemesini, çalışma içerisinde bu konularda söylenenlerden hareketle, bu eserin İbn Sînâ'ya karşı açık bir şekilde barındırdığı muhalif tavrın yanında en azından filozoflara karşı bazı felsefi konularda geliştirdiği tavır konusunda örtük bir Gazzâlî muhalefetini de barındırdığını da söyleyebiliriz.

\section{Kaynakça}

Aşukin, N.S. ve Butırskiy, N. P. vd., Politika Sözlü̈̆̈̈̈, çev.: Mazlum Beyhan, (İstanbul: Sosyal yay. 1979).

Beyhakî. Târîhu hukemâ'i'l-İslâm, tahk. Memduh Hasan Muhammed, (Kahire, Mektebetü's-Sekâfeti'd-Diniyye, 1996). 
Şehristânî'nin İbn Sînâ'ya Muhalefeti ve Gazzâlîci Muhalefet Taørını Dönüştürmesi

Çağrıcı, Mustafa. “Ebü'l-Berekât el-Bağdâdî”, DİA, c. X, ss. 300-1.

el-İsfehânî, Ragıp. el-Müfredât, tahk.: Muhammed Seyid Kîlânî, (Lübnan: Dâru'l-Ma'rife, ts.) s. 156.

Gazzâlî. Tehâfütü'l-felâsife, haz.: Maurice Bouyges, (Beyrouth: Imprimerie Catholique, 1927).

Hourani, George F. “The Chronology of Ghazali's Writings”, Journal of American Oriental Society, vol. 79, issue, 4, 1959, ss. 225-233.

İbn Hallikan. Vefayâtü'l-'ayân, tahk. İhsan Abbas, (Beyrut: Dârü's-Sadr, 1978), c. IV.

Kaya, Mahmut. "Tehâfütü'l-felâsife”, DİA, c. 40, ss. 313-14.

Madelung, Wilferd; Mayer, Toby. "Intoduction: Al-Shahristânî, İsma'ilism and Philosophy", Shahristânî, Strugling with the Philosopher, edit.and translated by Wilfred Madelung, Toby Mayer, (London: I.B. Tauris and Co. Ltd., 2001), s. 1-15.

Medkur, İbrahim. fíl-Felsefeti'l-İslâmiyyeti; Menhecü ve takbikuhu, (Kahire: Dârü'l- Me'ârif, 1976), 3.bs.

Shihadeh, Ayman. "From Ghazâlî to al-Râzî: 6th/12th Century Developments in Muslim Philosophical Theology", Arabic Science and Philosophy, vol. 15, 2005, ss. 141-79.

Subkî. Tabakâtu'ş-Şâfi'iyyeti'l-kübrâ, tahk.: Mahmûd Muhammed Tanahi, Abdülfettah Muhammed el-Hulv, (Kahire: Matba'atü 'Îsâ el-Bâbî elHalebî, 1964), c. VI.

Şehristânî. el-Milel ve'n-nihal, tahk.: Ahmet Fehmi Muhammed, (Lübnan: Dârü'l-Kütübi'l-'ilmiyye, 2009).

Şehristânî. Musâra'atü'l-felâsife, Struggling with the Philosopher: A Refutation of Avicenna's Metaphysics, translated by Wilferd Madelung, Toby Mayer, (London, I.B.Tauris, 2001).

Toktaş, Fatih. İslam Düşüncesinde Felsefe Eleştirileri, (İstanbul, Klasik yay.), 2004. s. 2.

Türker, Ömer. "Eş‘arî Kelamının Kırılma Noktası: Cüveynî’nin Yöntem Eleştirileri", İslam Araştırmaları Dergisi, sy. 19, 2008, ss. 1-23.

Uluç, Tahir. Sühreverdî'nin İbn Sînâ Eleştirisi, (İstanbul: İnsan yay., 2012).

Yıldırım, Ömer Ali. "Mutezile ve Nîşâbûr Fitnesi: Mihnetü Eşâ'ire”, Din Felsefesi Açısından Mutezile Gelen-Ek-i, Klasik ve Çă̆daş Metinler Seçkisi (II), Der.: Recep Alpyağıl, (İstanbul: İz yay. 2014), s. 696 - 713.

Yıldırım, Ömer Ali. Şehristân'̂'nin İbn Sînâ Eleştirisi, (İstanbul: Litera yay. 2016). 